\title{
COMPARATIVE STUDY OF REGULAR TEACHERS' SPECIAL EDUCATION PEDAGOGY COMPETENCE LEVEL IN ELEMENTARY AND SENIOR HIGH INCLUSIVE SCHOOL
}

\author{
Tias Martika ${ }^{\mathrm{a}}$, Abdul Salim ${ }^{\mathrm{b}}$ \\ ${ }^{a b}$ Special Education Program, Postgraduate Sebelas Maret University, Indonesia \\ E-mail: tiasmartika@gmail.com
}

\begin{abstract}
Comparative Study of Regular Teachers' Special Education Pedagogy Competence Level in Inclusive School Elementary and Senior High School Level. In general, this research aims to determine regular teachers' special education pedagogy competence level in the level of elementary and senior high inclusive school. Subject in this research was 38 regular teachers in elementary inclusive school and 45 regular teachers in senior high inclusive school. Data was collected through questionnaire. Data was analyzed by using normality test, homogeneity test, and t-independent test. Result of this research showed that data from both variables was normal, homogeny, and the average score of regular teachers' pedagogy competence in elementary school is 61.5 while the average score of regular teachers' pedagogy competence in senior high school is 48.78 . It can be concluded that regular teachers' special education pedagogy competence level in elementary school is higher than in senior high school.
\end{abstract}

Keywords: Pedagogy Competence, Regular School, Inclusive School

Inclusive education according to Government Regulation no. 70 year 2009 article 1 states that "Inclusive education is education system giving chance for all students with special needs and intelligence potential and/or special gifts to have education or lesson in education setting together with regular students." The implementation of inclusive education in Indonesia refers to the regulation above where children with special needs in inclusive school have education service appropriate with their needs.

Development of inclusive school in Indonesia is increasing as reported by Sunardi (2009) that presents data of the amount of inclusive school as follows.

\begin{tabular}{ccc}
\hline Year & $\begin{array}{c}\text { Amount of In- } \\
\text { clusive School }\end{array}$ & $\begin{array}{c}\text { Amount of Students } \\
\text { with Special Needs }\end{array}$ \\
\hline 2004 & 467 & 2,573 \\
2005 & 504 & 6,000 \\
2006 & 600 & 9,492 \\
2007 & 796 & 15,181 \\
\hline
\end{tabular}

The increasing amount of inclusive education school is not comparable with the development of service for students with special needs in inclusive school. There are some problems in the implementation of education service in inclusive school. One of the problems is teachers' condition in inclusive school as mentioned by Yusuf (2016) as follows.

It is not supported with sufficient teachers' quality yet. Class teachers are seen as not sensitive and proactive yet to students with special needs. The presence of special teacher. It is not supported with clear regulation about role, duty, and responsibility of each teacher yet. In doing education tasks, there is no regular discussion yet, no collaboration model as guidance, and no sufficient budget support.

The ideal inclusive school should have special education teachers with special education competence. However, fact in the filed shows that not all inclusive school has special education teachers. Gunarhadi (2012) finds out that $80 \%$ inclusive school in elementary school have no special education teachers yet. Another research conducted by Sunardi, Munawir, Gunarhadi, and Priyono (2010) also mentions that there are only 3 teachers worked as teacher's assistance in inclusive school. It makes students with special needs in inclusive school are handled by class teacher or subject teacher.

Regular teachers in inclusive school should own special competence in giving education service for students with special needs. According to Mulyasa (2012), competence is combination from knowledge, skill, value, and behavior reflected in thinking and acting behavior. Based on Regulation Number 14 Year 2005 about Teachers and Lecturers in article 10 paragraph 1, there are four competences should owned by a teacher, namely pedagogy competence, personality competence, social competence, and professional competence obtained from profession training. In this research, it will compare regular teachers' special education pedagogy competence level in the level of 
elementary and senior high inclusive school. Pedagogy competence is teachers' ability to students, designing, and teaching-learning process, learning evaluation, and students' development to actualize any kinds of potential they have (Suyanto and Jihad, 2013). Meanwhile, special education pedagogy competence is pedagogy competence should owned by a teacher in the field of special education to rise potential of students with special needs up and to serve education sufficient with their portion.

This research compares regular teachers' special education pedagogy competence level in the level of elementary and senior high inclusive school and its results will be used to group special education pedagogy competence difference among each education level.

\section{METHOD}

This research used comparative method. In this method, the data are compared and drawn into new conclusion. The word comparative itself is built from word 'compare'. It means compare to find out comparison from two concepts or more. According to Nazir (2005: 58), comparative research is a descriptive research used to determine basic answer of cause-effect, by analyzing causing factors of particular phenomenon.

Subject used in this research is 38 regular teachers of elementary school (Boyolali Regency, Surakarta city, and Karanganyar Regency) and 45 regular teachers of senior high school (Klaten Regency, Surakarta City, and Sukoharjo Regency). Data is collected through questionnaire of teachers' special education pedagogy competence level measurement by Gunarhadi et al. (2015). The measurement used is Cronbach Alpha reliability measurement with reliability level is 0.19 . Data was then analyzed by using SPSS 20 through normality test, homogeneity test, and T-independent test.

\section{FINDINGS AND DISCUSSION}

\section{Finding}

Measurement result of regular teachers' special education pedagogy competence level in inclusive school is as follows.

Table 1. Regular teachers' special education pedagogy competence level in elementary inclusive school

\begin{tabular}{cccccccc}
\hline Subject & Score & Subject & Score & Subject & Score & Subject & Score \\
\hline 1 & 70 & 11 & 73 & 21 & 56 & 31 & 46 \\
2 & 74 & 12 & 59 & 22 & 70 & 32 & 55 \\
3 & 64 & 13 & 44 & 23 & 54 & 33 & 61 \\
4 & 88 & 14 & 79 & 24 & 71 & 34 & 50 \\
5 & 56 & 15 & 42 & 25 & 69 & 35 & 61 \\
6 & 58 & 16 & 52 & 26 & 69 & 36 & 59 \\
7 & 58 & 17 & 54 & 27 & 69 & 37 & 74 \\
8 & 48 & 18 & 40 & 28 & 71 & 38 & 85 \\
9 & 71 & 19 & 40 & 29 & 77 & & \\
10 & 73 & 20 & 44 & 30 & 53 & & \\
\hline
\end{tabular}

Table 2 Regular teachers' special education pedagogy competence level in senior high inclusive school

\begin{tabular}{cccccccc}
\hline Subject & Score & Subject & Score & Subject & Score & Subject & Score \\
\hline 1 & 44 & 13 & 29 & 25 & 73 & 37 & 42 \\
2 & 50 & 14 & 54 & 26 & 71 & 38 & 66 \\
3 & 59 & 15 & 67 & 27 & 59 & 39 & 73 \\
4 & 63 & 16 & 39 & 28 & 49 & 40 & 35 \\
5 & 51 & 17 & 63 & 29 & 32 & 41 & 44 \\
6 & 46 & 18 & 47 & 30 & 53 & 42 & 46 \\
7 & 61 & 19 & 31 & 31 & 45 & 43 & 49 \\
8 & 32 & 20 & 42 & 32 & 44 & 44 & 37 \\
9 & 54 & 21 & 30 & 33 & 57 & 45 & 68 \\
10 & 54 & 22 & 45 & 34 & 33 & & \\
11 & 38 & 23 & 51 & 35 & 29 & & \\
12 & 59 & 24 & 48 & 36 & 33 & & \\
\hline
\end{tabular}




\section{Normality Test}

\begin{tabular}{llll}
\hline \multicolumn{3}{c}{ One-Sample Kolmogorov-Smirnov Test } \\
\hline & & Elementary & $\begin{array}{l}\text { Senior } \\
\text { High }\end{array}$ \\
\hline $\mathrm{N}$ & Mean & 61,50 & 45 \\
\hline $\begin{array}{l}\text { Normal } \\
\text { Parameters }\end{array}$ & Std. De- & 12,580 & 48,78 \\
& viation & & \\
\hline Most Extreme & Absolute &, 146 &, 073 \\
Differences & Positive &, 079 &, 073 \\
& Negative &,- 146 &,- 058 \\
\hline Kolmogorov-Smirnov Z &, 897 &, 488 \\
\hline Asymp. Sig. (2-tailed) &, 397 &, 971 \\
\hline
\end{tabular}

a. Test distribution is Normal.

b. Calculated from data.
Based on the result of normality test by using Kolmogorov Smirnov test, it is obtained that Sig. data of elementary school is $0.397(0.397>0.05)$. It means that sample data of elementary school is distributed normally. Also for the value of Sig of senior high school is $0.971(0.971>0.05)$ it means that sample data of senior high school is distributed normally.

\section{Homogeneity Test}

\begin{tabular}{cccc}
\hline \multicolumn{4}{c}{ Test of Homogeneity of Variances } \\
\hline Score \\
\hline Levene Statistic & df1 & df2 & Sig. \\
, 052 & 1 & 81 &, 821 \\
\hline
\end{tabular}

From table above, it shows that significance value is 0.821 . Because p-value is $0.821>0.05$, then, data was taken from homogeny sample.

\section{T-Test}

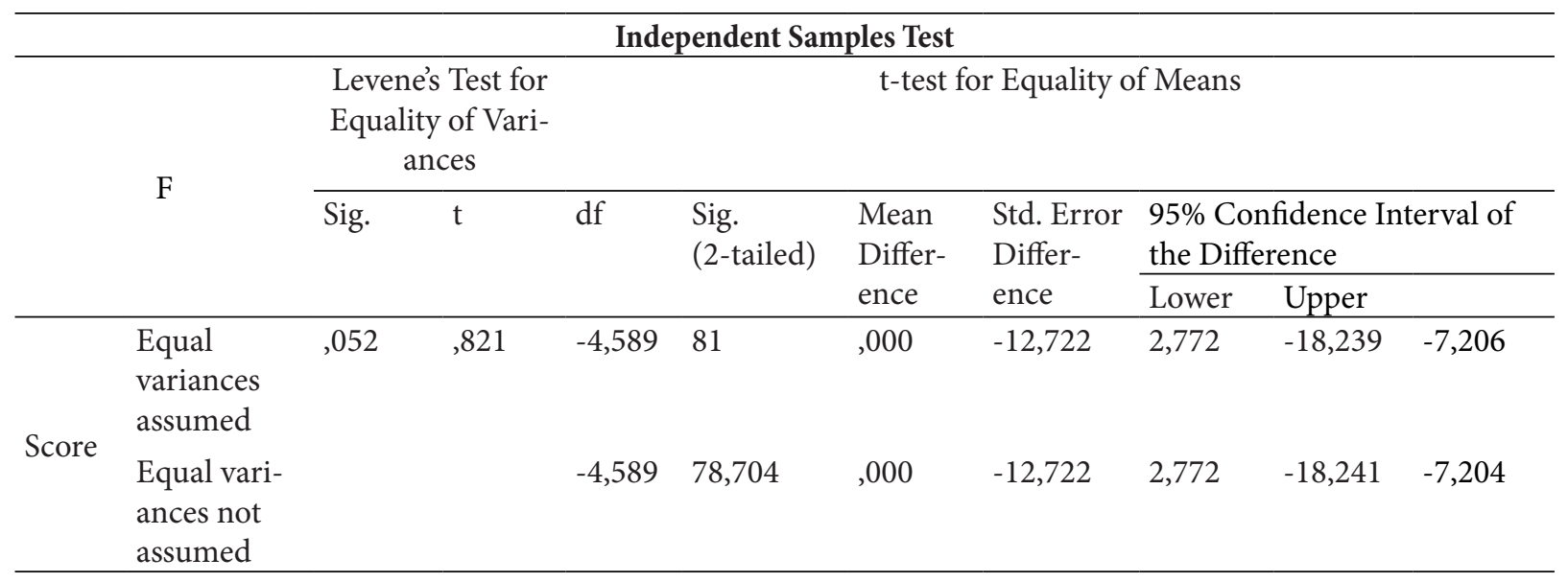

Based on table above, it is obtained sig (2-tailed) value is $0.000<0.005$. According to decision making basis in Independent Sample T-Test, it can be concluded that there is difference between average score of regular teachers' special education pedagogy competence level in the level of elementary school and senior high school.

\begin{tabular}{llllll}
\hline \multicolumn{5}{c}{ Group Statistics } \\
\hline Group & $\mathrm{N}$ & Mean & $\begin{array}{l}\text { Std. De- } \\
\text { viation }\end{array}$ & $\begin{array}{l}\text { Std. } \\
\text { Error } \\
\text { Mean }\end{array}$ \\
\hline Score & SD & 38 & 61,50 & 12,580 & 2,041 \\
& SMA & 45 & 48,78 & 12,588 & 1,876 \\
\hline
\end{tabular}

Based on table above, it show that average score of regular teachers' special education pedagogy competence level in the level of elementary school is
61.50 and the average score of regular teachers' special education pedagogy competence level in the level of senior high school is 48.78. Based on the data, it can be presented in the form of diagram as follows.

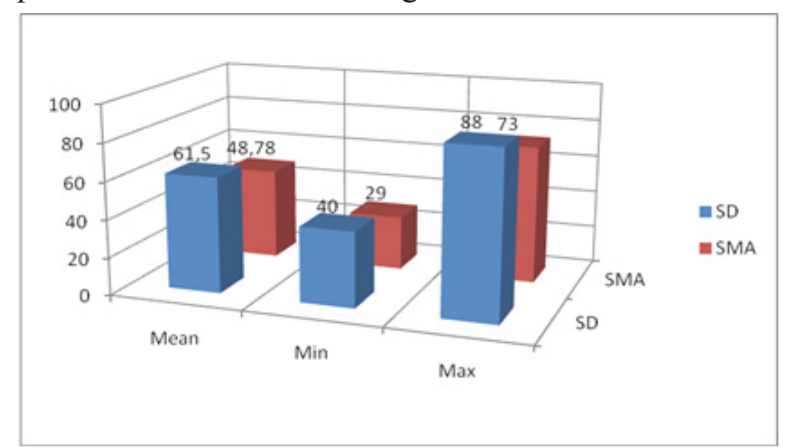

Figure 1. Regular teachers' special education pedagogy competence level in the level of elementary and senior high school 


\section{Discussion}

Average score of regular teachers'special education pedagogy competence level in the level of elementary school is 61.50 (good) and the average score of regular teachers' special education pedagogy competence level in the level of senior high school is 48.78 (fair). This result is in line with research conducted by Gunarhadi, Sunardi, Andayani, and Anwar (2016) about regular teachers' comprehension about special education in elementary inclusive school. Result of the research is $16 \%$ is in low level, $64 \%$ is in moderate level, and $20 \%$ is in high level. Meanwhile, research conducted by Martika, Salim, and Munawir (2016) about teachers' pedagogy competence in senior high inclusive school states that $27 \%$ is in very low level, $44 \%$ is in low level, $22 \%$ is in fairly level, $7 \%$ is in good, and $0 \%$ is in very good.

Bukvic, Z (2014) observes about teachers' competence in inclusive school. The result states that $70 \%$ teachers do not have or limited knowledge about teaching students with special needs, and most of their attitudes are negative. However, teachers with positive attitude to inclusive education prefer not to teach students with special needs.

It is a fact that regular teachers' special education pedagogy competence level in elementary and senior high inclusive school has significant difference. It is because some factors stated by Gunarhadi et al (2016),

\section{REFERENCES}

Bukvic, Z. (2014). Teachers competency for inclusive education. The European Journal of Social and Behavioural Sciences (EJSBS), 1586-1590. http:// dx.doi.org/10.15405/ejsbs.141

Gunarhadi, Sugini, Tri RejekiAndayani. (2012). Teachers' Performance in Inclusive Education. Procceding, Asean Academic Community International Conference, HS-36-PF, 48-51.

Gunarhadi, Sunardi, Andayani, T.R., \& Anwar, M. (2016).Pedagogic mapping of teacher competence in inclusive schools.Prosiding ICTTE, 1 (1), 389394.

Martika, T., Salim, A., \& Yusuf, M. (2016). Understanding Level of Regular Teachers' Competency Understanding to Children with Special Needs in Inclusive School.European Journal of Special Education Research, 1(3), 3038. that there are should at least two reasons to discuss why teachers have low comprehension about special education. First, those teachers do not have special educationqualification. For them, inclusive education is new trends. Children with special needs are beyond their experience that they've never imagined before. Second, people with special education qualification do not act as class teacher in inclusive school. Therefore, they do not have fully responsible of education service especially for children with special needs in their school (Sunardi et al, 2010). Another reason is that in inclusive school, teachers have little chance to participate in training in the field of special education.

\section{CONCLUSION AND SUGGESTION}

Conclusion of this research is that average score of regular teachers' special education pedagogy competence in elementary school is higher than in senior high school.

School should plan training program to increase special education pedagogy competence level for regular teachers in inclusive school. Inclusive school having special education teacher can be information source in special education pedagogy competence comprehension for regular teachers. It needs to be created peer teaching for regular teachers so that they can share their problems faced in inclusive school.

Mulyasa, E. (2012). Standar Kompetensidan Sertifikasi Guru. Bandung: PT. RemajaRosdakarya.

Nazir.(2005). MetodePenelitian. Jakarta: Ghalia Indonesia.

Sunardi., Yusuf, M., Gunarhadi., Priyono. (2010). TheImplementasi of Inclusive Education for Student With Special Needs in Indonesia. LaporanPenelitian (International Collaboration Research UNS With The University of Pittsburgh, USA). Surakarta : LPPM UNS.

Suyanto, Jihad, A.(2013). Menjadi guru Profeional. Jakarta :EsensiErlangga Group

Undang-undangRepublik Indonesia Nomor 14 Tahun 2005 tentang guru dandosen 